\title{
Penerapan Software Akuntansi Online Sebagai Penunjang Pencatatan Laporan Keuangan
}

\section{Implementation of Online Accounting Software As Supporting Of Financial Statement}

\author{
Untung Rahardja ${ }^{1}$, Qurotul Aini ${ }^{2}$, Marviola Hardini ${ }^{3}$ \\ ${ }^{1}$ Dosen Sistem Informasi STMIK Raharja, ${ }^{2}$ Dosen Sistem Informasi STMIK Raharja, \\ ${ }^{3}$ Mahasiswa \\ STMIK Raharja Jurusan Teknik Informatika \\ e-mail: ${ }^{1}$ untung@raharja.info, ${ }^{2}$ aini @ raharja.info, ${ }^{3}$ marviola@ raharja.info
}

\begin{abstract}
Abstrak
Informasi keuangan yang telah dibuat oleh akuntan saat ini dapat dengan mudah diakses oleh bagian pimpinan. Namun ada 3 (tiga) kendala yang ditemukan oleh pimpinan maupun para akuntan, salah satunya yaitu menyajikan informasi dengan menggunakan tabel membutuhkan ketelitian yang sangat tinggi untuk memastikan setiap informasi nominal uang yang dicantumkan ke dalam tabel tersebut itu benar dan hal tersebut menghabiskan waktu yang lumayan lama. Guna memudahkan akuntan dalam melakukan pencatatan laporan keuangan serta pimpinan yang melakukan pengecekkan dalam informasi yang disajikan, Software Jurnal (Software Akuntansi Online) akan menyajikan informasi berupa tanggal, kode produk, nama produk, kuantitas, total pendapatan, rata-rata pendapatan. Software Jurnal (Software Akuntansi Online) memiliki tingkat keamanan yang bagus karena diamankan dengan teknologi yang setara atau lebih kuat dari yang dipakai Bank. Software Jurnal (Software Akuntansi Online) menggunakan encryption AES-256 agar pihak yang tidak bertanggung jawab tidak dapat mengakses data dengan mudah. Software Jurnal (Software Akuntansi Online) juga menggunakan 2056-bit SSL certificate untuk mengamankan koneksi internet. Dalam penelitian ini, terdapat 3 (tiga) keuntungan dalam Software Jurnal (Software Akuntansi Online). Dengan hadirnya kegiatan penelitian kali ini diharapkan agar Software Jurnal (Software Akuntansi Online) dapat meningkatkan mutu laporan keuangan dalam proses pencatatan laporan pendapatan.
\end{abstract}

Kata kunci-Akuntansi, Laporan Keuangan, Software Online, Jurnal

\section{Abstract}

The financial information that has been made by the accountant can now be easily accessed by the part of the leadership. However there are 3 (three) the difficulties faced by the leaders as well as accountants, one that is present information using the table need a very high accuracy to ensure every information nominal money that are listed into the table it's right and this takes quite a long time. To make it easier for accountants in performing record-keeping financial reports as well as the leadership of examining the information presented, Jurnal Software (Accounting Software Online) will be presenting information in the form of date, product code, product name, quantity, total income, average income. Jurnal Software (Online Accounting Software) has a good level of security because it is secured with technology equal or stronger than that used a Bank. Jurnal Software (Online Accounting Software) wearing encryption AES-256 so that the data cannot be viewed by unauthorized persons. Jurnal Software (Online Accounting Software) is also a secure internet connection with 2056-bit SSL 
certificate. In this research, there are 3 (three) advantages in the Jurnal Software (Online Accounting Software). The existence of the study expected that Jurnal Software (Online Accounting Software) this can improve the quality of financial reporting in the process recording the income report.

Keywords-Accounting, Earnings Reports, Software Online, Jurnal

\section{PENDAHULUAN}

Seiring perkembangan teknologi yang semakin cepat dan perubahan terjadi begitu signifikan [1], kebutuhan akan hal yang berkaitan erat dengan lingkungan kehidupan semakin banyak [2], dalam penelitian ini pengolahan data transaksi secara manual tidak menjadi masalah, tetapi yang menjadi masalah apabila banyaknya transaksi yang ada diolah menggunakan sistem pencatatan manual. Hal tersebut akan menghambat pekerjaan, karena banyaknya transaksi yang harus di input, serta tahapan-tahapan yang harus dibuat, jika menggunakan pencatatan secara manual [3]. Yang ditugaskan dalam melakukan penyusunan laporan keuangan adalah seorang akuntan sebagai sarana untuk memonitor kemajuan suatu perusahaan atau dapat juga digunakan sebagai sarana pengambilan keputusan [4].

Dimana suatu perubahan diperlukan dalam berbagai aspek misalkan bentuk penyajian informasi, sehingga informasi dapat efektif dan mudah dipahamiSumber informasi dari sebuah laporan keuangan banyak dijadikan pedoman dalam pengambilan sebuah keputusan bagi para kreditur, pengamat ekonomi, pemegang saham, dan pemerintah sesuai dengan kepentingan yang ada, serta merupakan pedoman perincian pada setiap prestasi operasional suatu perusahaan ketika Analisa Rasio Keuangan dilakukan [5]. Dengan adanya laporan keuangan maka akan diperoleh gambaran mengenai bagaimana perkembangan perusahaan, sehingga yang berkepentingan terhadap perkembangan perusahaan dapat mengadakan analisis terhadap semua data keuangan yang terdapat dalam laporan keuangan [6].

Resiko terjadi kesalahan timbul ketika melakukan penyusunan laporan keuangan lebih besar bila dilakukan secara manual dan data pun dinilai masih kurang akurat [7], maka dari itu pemanfaatan teknologi informasi yaitu komputer dapat mempercepat hal yang sedang dikerjakan serta lebih akurat khususnya dalam perhitungan pada bidang akuntansi [8].

Dalam setiap laporan keuangan juga harus ada yang disebut dengan Balanced atau di sebut pula dengan berimbang, maknanya adalah dapat membuat serta menghasilkan laporan keuangan yang telah terukur dari dua sudut pandang secara berimbang baik internal dan eksternal ataupun jangka panjang dan pendek [9].

Laporan pendapatan yang telah diolah sedemikian rupa merupakan salah satu poin penting yang ada dalam ha keuangan sebagai syarat kelengkapan pembuatan laba rugi [10]. Laporan pendapatan yang kini berjalan prosesnya masih diolah secara manual di mana seorang akuntan harus merekap data dari kumpulan berkas yang telah disiapkan seperti kwitansi ke dalam bentul exce, kemudian di hitung menggunakan kalkulator ataupun rumus yang terdapat dalam excel tersebut [11]. Sementara era globalisasi saat ini berkembang begitu pesat, dan sudah mrambah kedalam bidang akuntansi keuangan seiring dengan user yang semakin sadar akan pentingnya ilmu pengetahuan terutama bidang teknologi [12].

Berbagai macam cara dapat dilakukan supaya kualitas laporan yang tersedia menjadi semakin meningkat salah satunya dengan memanfaatkan teknologi masa kini [13]. Dimana sebuah informasi laporan keuangan dikatakan bermutu tinggi apabila informasi yang digunakan sebagai pendukung seluruh kegiatan transaksional perseorangan ataupun perusahaan dilengkapi dengan pengontrolan sistem yang maksimal untuk dapat memonitor kinerja, sehingga informasi yang dihasilkan dan ditampilkan tersebut dapat mengantisipasi kemungkinan terjadinya suatu kesalahan atau kekeliruan fatal dikemudian hari [14]. Sedangkan sumber daya manusia di tuntut untuk bisa lebih kreatif serta bisa memanfaatkan perkembangan teknologi secara maksimal sesuai kebutuhan yang semakin lama semakin complicated [15]. 
Dimana perubahan dirasa sangat dibutuhkan dalam berbagai aspek misalkan bentuk penyajian informasi, sehingga informasi dapat dinilai efektif dan dapat mudah dipahami [16]. Jurnal adalah Software Online di bidang akuntasi dengan laporan keuangan lengkap seperti, neraca keuangan, arus kas, laba-rugi, dan lainnya. Jurnal dapat di akses dengan menggunakan WiFi atau koneksi via internet dimanapun user berada. Dengan ini, tidak lagi perlu untuk download atau install aplikasi apapun di komputer. Hanya perlu mendaftar, login, dan mulai gunakan Software tersebut sebagai pendukung usaha kapanpun, dimanapun [17].

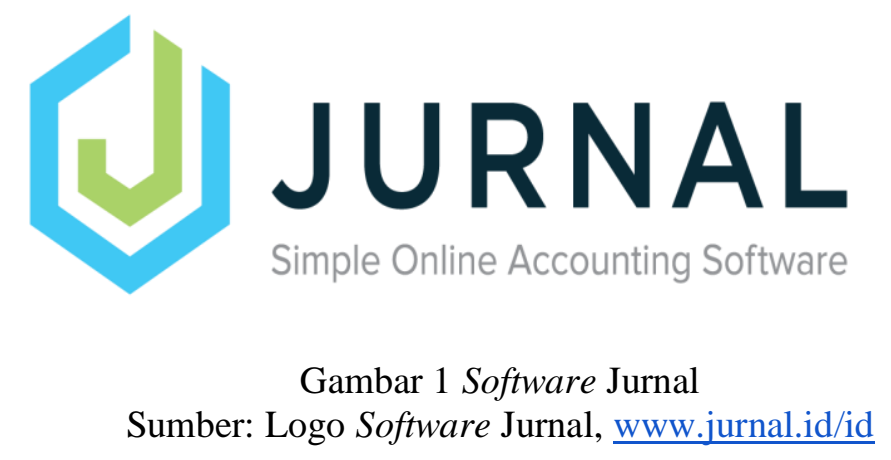

Sebagai bentuk fasilitas dalam mempermudah pencatatan laporan keuangan, telah hadir sebuah Software Jurnal (Software Akuntansi Online). Di mana Software Jurnal (Software Akuntansi Online) adalah sebuah Software yang baru lahir dan masih dalam proses pengembangan yang merupakan sebuah Software penunjang pencatatan laporan keuangan yang dapat diakses secara Online [18] sangatlah penting guna memberikan suatu solusi dan merupakan salah satu alat bantu yang cukup baik dalam menangani sistem yang belum optimal (manual) [19]. Bagi masyarakat awam khususnya para akuntan suatu perusahaan tentu dengan hadirnya sebuah Software akuntansi Online menjadi hal yang begitu penting karena dengan begitu dapat dengan mudah mengelola keuangan secara terperinci, tanpa terlewat atau terjadi banyak kekeliruan [20]. Salah satu metode dalam pengendalian suatu sistem berbasis Online ialah dengan melakukan otorisasi berdasarkan kriteria tertentu terhadap para user, pengendalian ini digunakan sebagai upaya pencegahan pada hal tidak di inginkan [21].

Software Jurnal telah memikirkan hal ini dengan baik di mana data diamankan dengan teknologi yang setara atau lebih kuat dari yang dipakai Bank. Menggunakan encryption AES256 agar data yang ada tidak dapat dilihat oleh para pihak yang tidak berwenang. 2056-bit SSL certificate juga telah digunakan untuk mengamankan koneksi internet [22]. Dengan adanya fasilitas keamanan yang disediakan ini juga dihaarapkan dapat memberikan informasi secara lebih cepat dan akurat langsung ke tangan pimpinan jika telah memiliki akun. [23].

Permasalahan pertama yang dihadapi adalah jumlah transaksi yang sangat banyak setiap harinya dengan proses pengolahan data yang masih secara manual. Pengolahan data tersebut menjadi sangat tidak efisien dan efektif, karena kemungkinan besar akan adanya kesalahan dalam penghitungan serta banyaknya tahapan yang harus dilakukan.

Untuk membuktikan bahwa laporan pendapatan telah sesuai jumlahnya dengan transaksi yang ada maka akuntan harus membawa berkas seperti kwitansi yang membuktikan bahwa semua transaksi telah di input dan dilaporkan dengan baik untuk diberikan kepada kepala bagian keuangan agar laporan tersebut bisa di verifikasi keabsahannya. Pengecekkan data tersebut masih dilakukan secara manual di mana setiap harinya minimal terdapat 200 transaksi yang memakan waktu 6 jam untuk dilakukan penghitungan hingga mendapatkan total yang sesuai dan tepat. 


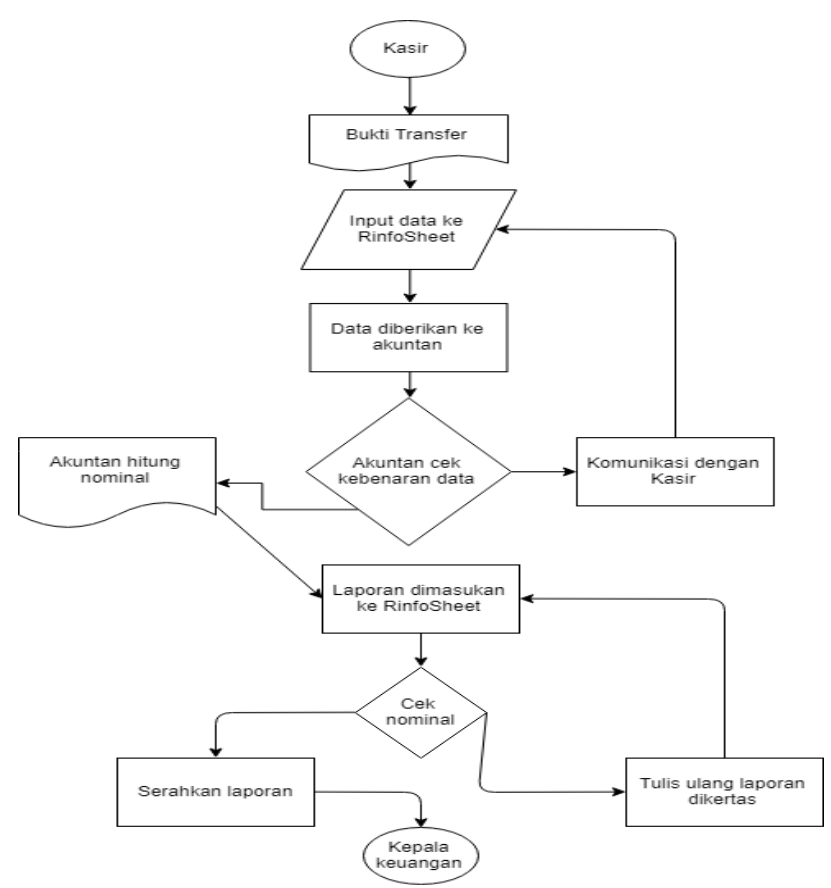

Gambar 2 Alur Pengecekkan Laporan Pendapatan

Gambar 2. Menjelaskan bahwa untuk melakukan pengecekkan dan pencatatan pendapatan masih dilakukan secara manual oleh akuntan. Lalu akuntan tersebut masih harus menghitung kembali apakah transaksi yang telah dicatat memiliki jumlah yang sudah benar sesuai berkas yang ada.

Permasalahan kedua yang dihadapi adalah pencatatan yang diproses secara manual dapat diubah dengan menggunakan Software akuntansi yang telah tersedia di komputer suatu perusahaan atau instansi yang membutuhkan, tetapi itu saja masih tidak maksimal karena jika ingin mengerjakan laporan maka akuntan harus ke kantor atau menginstal Software yang dibutuhkan terlebih dahulu sehingga kemungkinan besar menjadi sangat memakan waktu yang banyak.

Dan permasalahan yang terakhir adalah ketika laporan keuangan yang berbentuk dokumen fisik atau kertas telah selesai dibuat dan dilaporkan kepada kepala bagian keuangan maka jika ada kesalahan akan memakan banyak kertas untuk membuat laporan yang baru, hal itu sangat membuang-buang kertas dan juga berakibat besar terhadap lingkungan.

\section{METODE PENELITIAN}

Metode Penelitian yang digunakan pada penelitian ini mengacu pada 2 (dua) teknik pengumpulan data, yaitu:

a. Metode Studi Pustaka, dimana metode ini berguna untuk mengetahui informasi dari berbagai sumber literature seperti jurnal, buku, internet, makalah, dan sebagainya yang berkaitan erat dengan penelitian dimana bermanfaat sebagai referensi, serta mengetahui ruang lingkup penelitian yang memiliki kesamaan di bidang akuntansi ini., adapun referensi dalam pembuatan jurnal ini:

1) Penelitian ini dilakukan oleh Susan Rachmawati dan Nurjanah (2017) yang berjudul "Implementasi Data Keuangan Dengan Zahir Accounting Pada PT. Anugerah Analisis Sempurna”. Penelitian ini menjelaskan tentang penggunaan Zahir Accounting Versi 5.1 yang dapat menjadi upaya pemecahan masalah dalam pengolahan data keuangan pada PT Anugerah Analisis Sempurna. Mengurangi kesalahan dalam pengolahan data yang dilakukan dan dapat mempercepat proses pengolahan data akuntansi [24]. 
2) Penelitian ini dilakukan oleh Sri Maharsi (2000) yang berjudul "Pengaruh Perkembangan Teknologi Terhadap Bidang Akuntansi Manajemen". Penerapan teknologi informasi mengakibatkan banyak perubahan pada bidang akuntansi manajemen. Dimana setiap perkembangan kegiatan perusahaan harus disesuaikan dengan Akuntansi Manajemen [25].

3) Penelitian ini dilakukan oleh Dini Hari Pertiwi (2015) yang berjudul "Perancangan Sistem Informasi Aset Tetap Perusahaan Menggunakan Metode Pengembangan Evolusioner". Perancangan sistem informasi aset tetap perusahaan ini membantu pihak perusahaan dalam perhitungan nilai investasi terhadap suatu aset tetap yang dimiliki oleh perusahaan karena perhitungan penyusutan aset prosesnya terdapat dalam sistem informasi [26].

4) Penelitian ini dilakukan oleh Ni Made Sri Rukmiyati dan I Ketut Budiartha (2016) yang berjudul "Pengaruh Kualitas Sistem Informasi, Kualitas Informasi dan Perceived Usefulness Pada Kepuasan Pengguna Akhir Software Akuntansi (Studi Empiris Pada Hotel Berbintang di Bali)". Di mana penelitian yang dilakukan menunjukkan bahwa semua variabel bebas merupakan suatu bagian penjelas yang sangat signifikan pada variabel terikat, sehingga penelitian ini layak menggunakan metode tersebut. Dan dari tiga hipotesis yaitu pengaruh kualitas perceived usefulness, informasi, dan kualitas sistem informasi yang telah diuji ternyata sangat berpengaruh positif terhadap tingkat kepuasan yang dirasakan oleh pengguna Software akuntansi [27].

5) Penelitian ini dilakukan oleh Rizki Rudiantoro dan Sylvia Veronica Siregar (2012) yang berjudul "Kualitas Laporan Keuangan UMKM Serta Prospek Implementasi SAK ETAP". Dalam penelitian ini disimpulkan bahwa pelaporan keuangan dan pembukuan adalah hal yang memiliki kendali penting dalam perkembangan dan pertumbuhan suatu usaha. Sedangkan kualitas laporan keuangan UMKM sendiri saat ini masih terbilang rendah [28].

6) Penelitian ini dilakukan oleh Taufik Saleh, Darwanis, dan Usman Bakar yang berjudul "Pengaruh Kualitas Sistem Informasi Terhadap Kualitas Informasi Akuntansi Dalam Upaya Meningkatkan Kepuasan Pengguna Software Akuntansi Pada Pemerintah Aceh". Dapat disimpulkan bahwa penelitian ini menjelaskan bahwa tingkat kepuasan penggunaan Software akuntansi sangat berpengaruh terhadap kualitas laporan keuangan yang dihasilkan. Di mana informasinya harus akurat, mudah dipahami, detil dan tepat waktu [29].

7) Penelitian ini dilakukan oleh Aria Weharima yang berjudul "Manfaat Akuntansi Pertanggungjawaban Sebagai Alat Bantu Bagi Manajemen Dalam Menunjang Efektivitas Pengendalian Biaya Pemasaran". Dengan penggunaan akuntansi secara maksimal dapat sangat bermanfaat terhadap pengendalian efektivitas biaya pemasaran supaya bisa bersaing dengan perusahaan lainnya [30].

b. Metode Observasi (Pengamatan Langsung), metode ini merupakan sebuah pengamatan pada sistem yang berkaitan dengan penelitian yang sedang dilakukan. Sehingga data yang terkumpul dapat digunakan sebagai informasi lebih lanjut mengenai siklus keuangan serta dapat menghasilkan sebuah laporan untuk menerapkan sebuah sistem akuntansi yang optimal.

\section{HASIL DAN PEMBAHASAN}

Sudah dijelaskan pada permasalahan di atas poin utama dari masalah yang ada yaitu proses pencatatan laporan yang masih manual dan masih memungkinkan adanya kesalahan nominal, maka dapat disimpulkan pemecahan masalah nya digunakanlah sebuah Software Jurnal (Software Akuntansi Online) dengan alur sebagai berikut: 


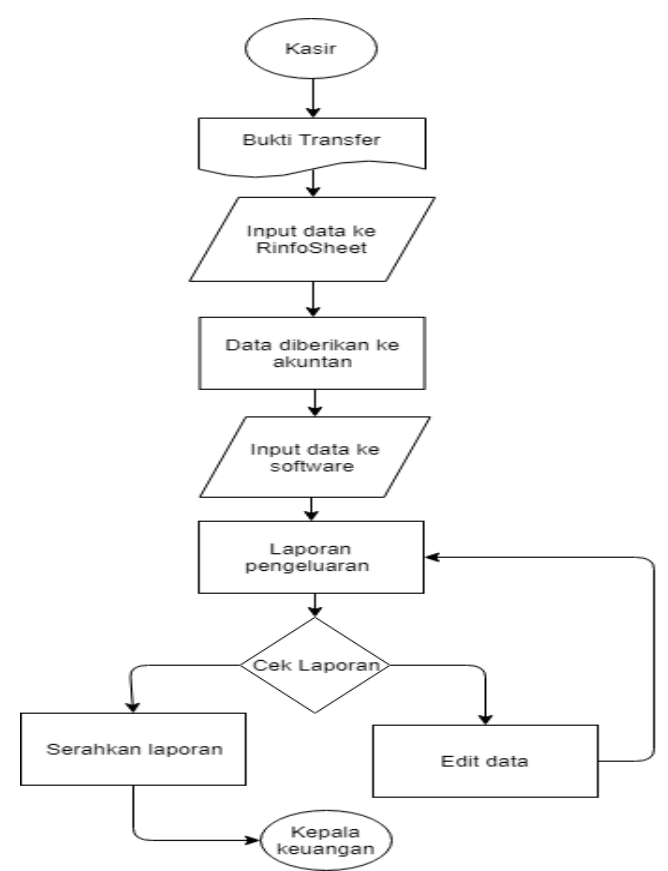

Gambar 3 Alur Masuknya Data Pada Software Jurnal

Gambar 3. Merupakan alur sistem di Software Jurnal dan dari alur tersebut dapat dijelaskan bahwa untuk melakukan proses pencatatan pendapatan dapat dilakukan secara Online dan cepat.

Dengan adanya Software Jurnal proses pencatatan pendapatan dapat dilakukan secara Online dan mandiri oleh akuntan. Sehingga kapanpun dan di manapun dapat dilakukan pencatatan pendapatan dengan cepat, kemudian laporan tersebut akan diverifikasi ketepatannya oleh kepala bagian keuangan. Lalu mulai diterapkanlah sebuah Software akuntansi Online dengan nama Jurnal (Software Akuntansi Online).

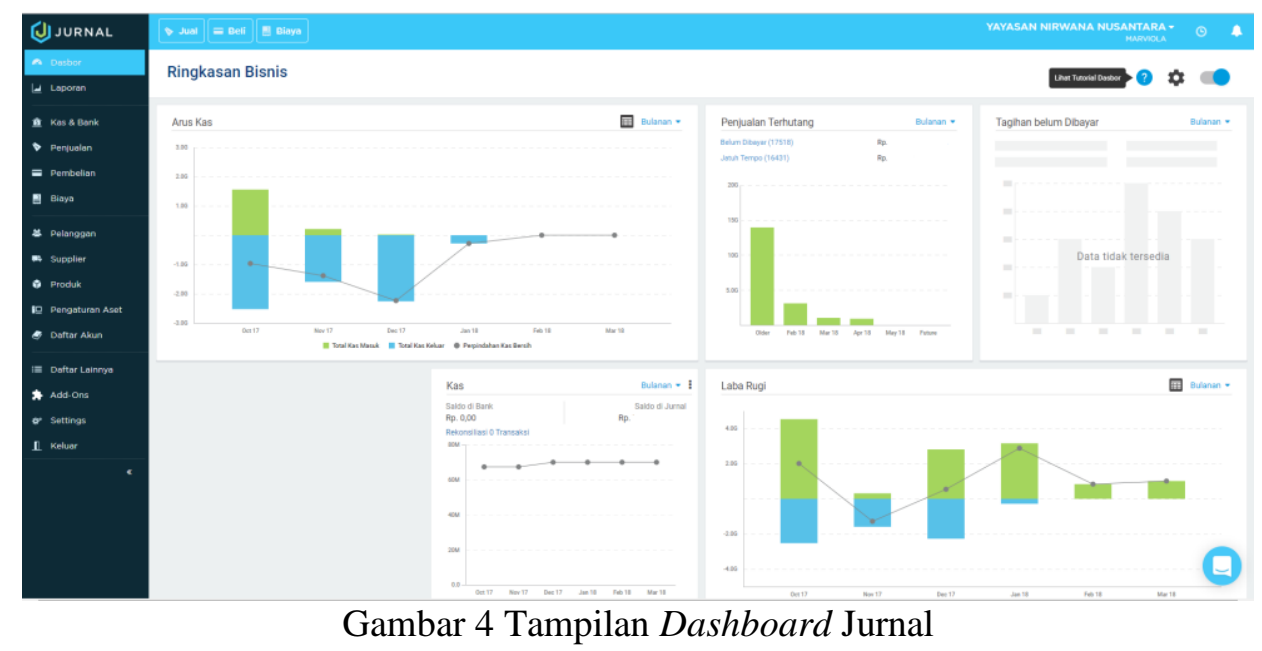

Gambar 4. Tampilan dashboard Jurnal berisi informasi semua laporan keuangan dengan data yang telah di input ke dalam Jurnal.

Menu penjualan yang terdapat didalam Software Jurnal sudah diimplementasikan di Yayasan Nirwana Nusantara dalam mendukung pelaksanaan pencatatan laporan keuangan maupun memonitor keuangan salah satunya laporan pendapatan. Kepala bagian keuangan, 
akuntan atau siapa pun yang telah memiliki akun dalam Jurnal dapat melihat dan membaca bahkan mengolah data transaksi yang ada dimulai dari menyiapkan data transaksi berupa excel, akses Software Jurnal dengan menggunakan akun yang sudah terdaftar, mengakses menu penjualan yag terdapat dalam Jurnal, memilih menu import data, menyesuaikan data supaya siap untuk di import dengan template yang telah disediakan oleh Jurnal, memastikan data yang akan diimport sudah benar, kemudian import data transaksi tersebut, dan setelah selesai diimport akan ditampilkan semua data transaksi yang telah terimport dengan rapi. Berikut akan dijabarkan beberapa contoh hasil dari uji coba dan implementasi Software Jurnal berdasarkan data transaksi factual yang ada pada database Software Jurnal sebagai tempat penelitian dan uji coba dilaksanakan.

1) Tampilan Home dari Jurnal

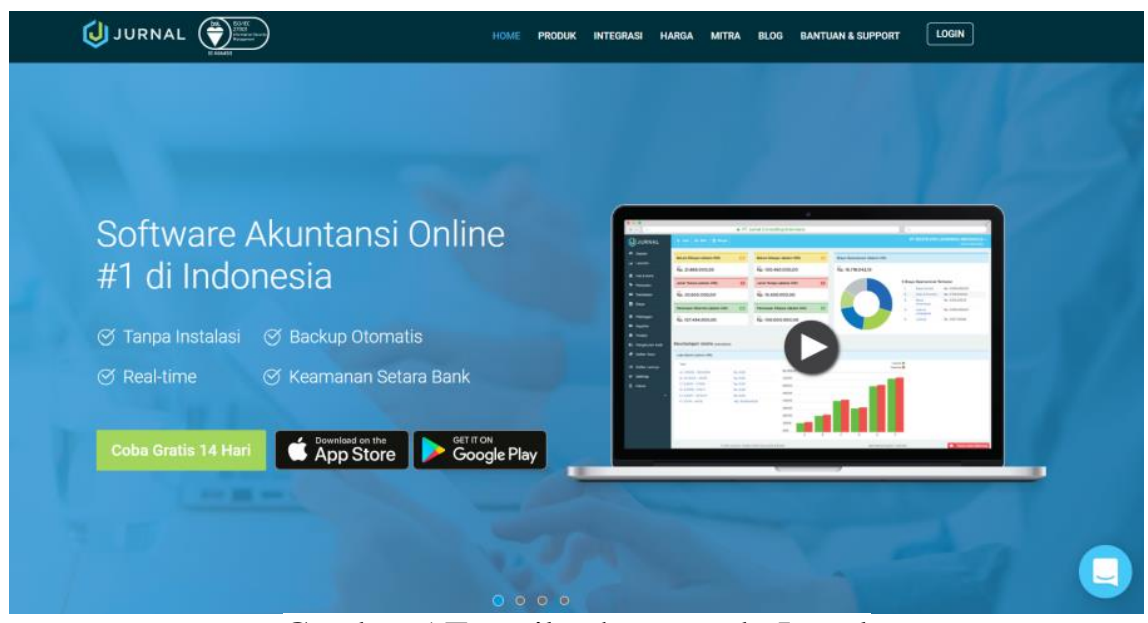

Gambar 5 Tampilan home pada Jurnal

Gambar 5. Merupakan tampilan dari home Jurnal yang digunakan untuk dapat masuk ke dalam program Jurnal tersebut.

2) Tampilan Login dari Jurnal

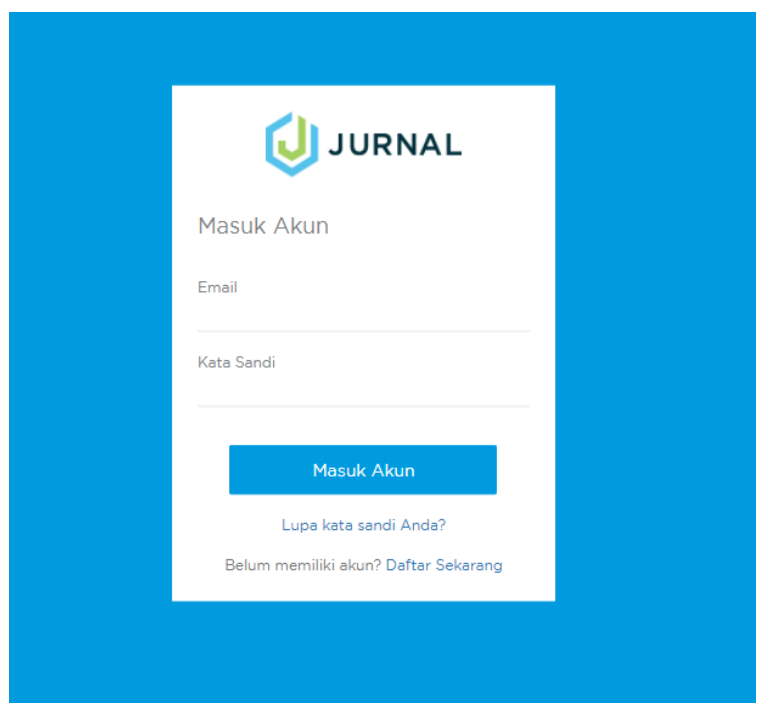

Gambar 6 Tampilan login pada Jurnal 
Gambar 6. Merupakan tampilan login Jurnal dengan menggunakan email serta password yang sudah terdaftar.

3) Tampilan menu penjualan dari Jurnal

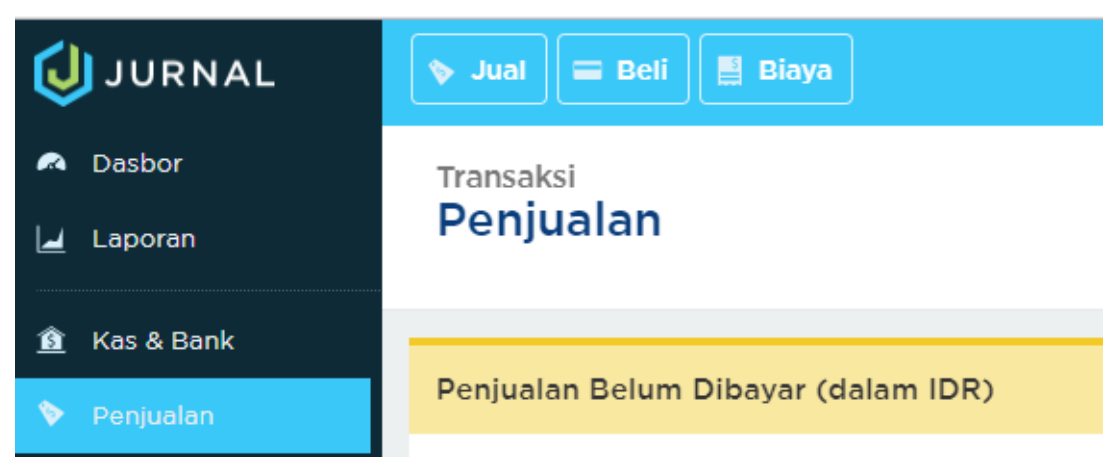

Gambar 7 Merupakan tampilan menu penjualan pada Jurnal

Gambar 7. Di dalam Jurnal terdapat 15 tab yang dapat di akses oleh para user pemilik akun Jurnal di mana salah satunya merupakan tab penjualan yang digunakan untuk melakukan pencatatan pendapatan.

4) Tampilan saat data di input ke program

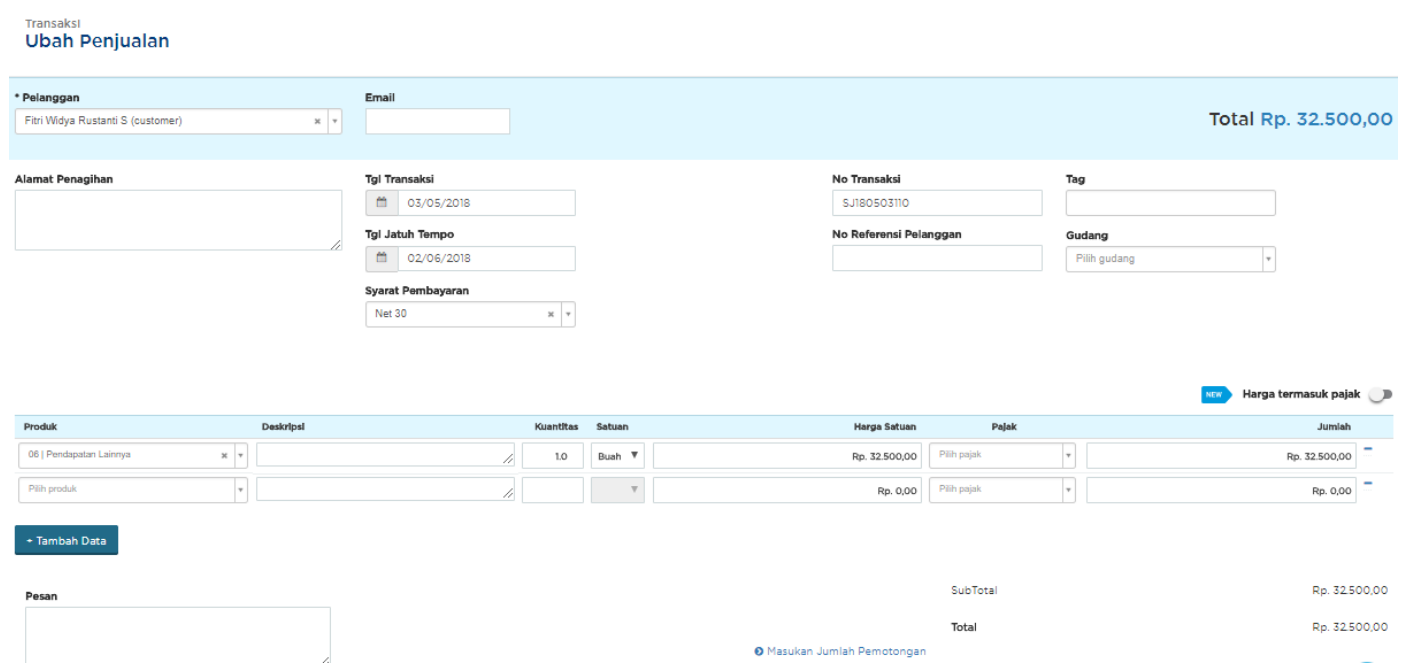

Gambar 8 Tampilan proses input data kedalam program Jurnal.id

Gambar 8. Pada gambar tersebut di butuhkan data dari bagian kasir agar dapat terdata kedalam program, sesuai dengan pembayaran yang dilakukan oleh setiap mahasiswa, kemudian jika data sudah dipastikan benar maka kita dapat menekan tombol "buat penjualan" supaya data yang kita masukan dapat tercatat dengan baik di dalam program.

5) Tampilan transaksi yang telah di input ke dalam Jurnal 


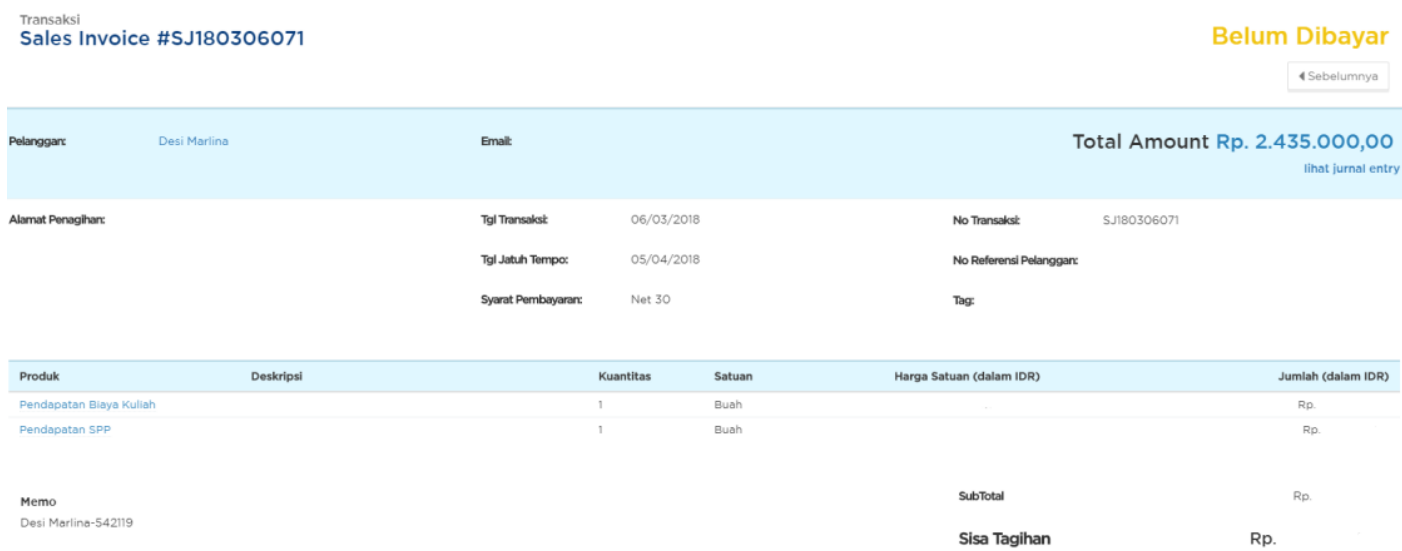

Gambar 9 Tampilan transaksi setelah tercatat ke dalam Jurnal

Gambar 9. Transaksi yang sudah di input ke dalam Software Jurnal akan ditampilkan dengan menyertakan info nama mahasiswa, tanggal, nomor transaksi, jenis pendapatan, kuantitas, jumlah pendapatan nya.

6) Tampilan daftar pendapatan dari Jurnal

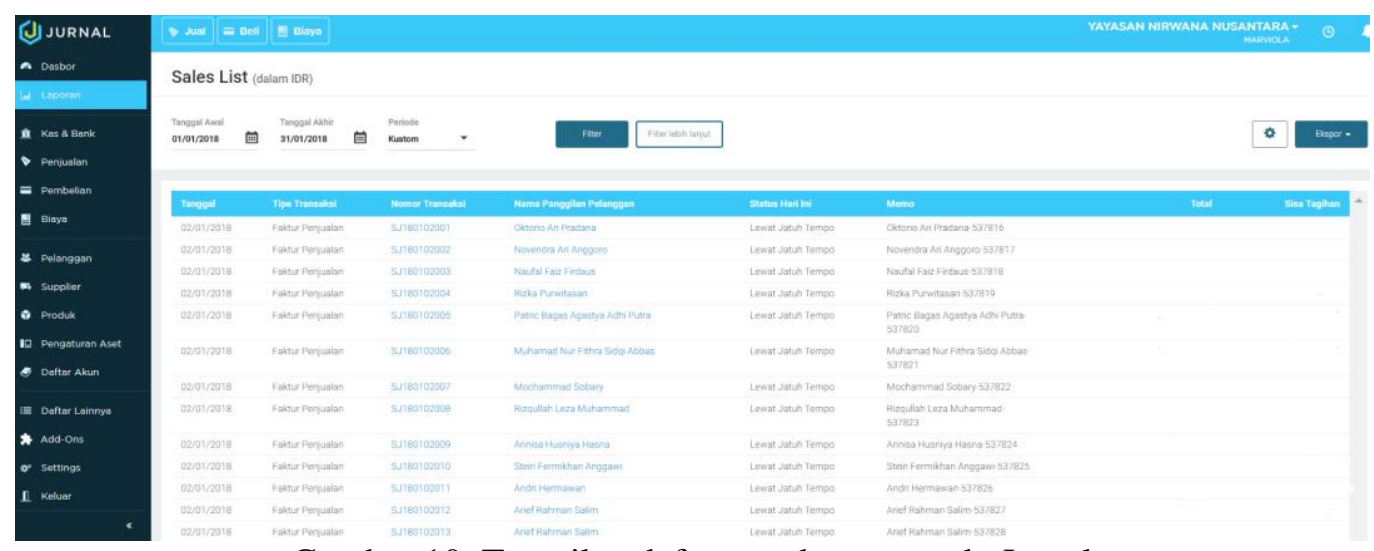

Gambar 10 Tampilan daftar pendapatan pada Jurnal

Gambar 10. Semua yang memiliki akses ke menu laporan dapat mengakses daftar penjualan dan menentukan transaksi yang ingin ditampilkan sesuai dengan periode laporan pendapatan yang user tentukan.

7) Tampilan laporan laba rugi 


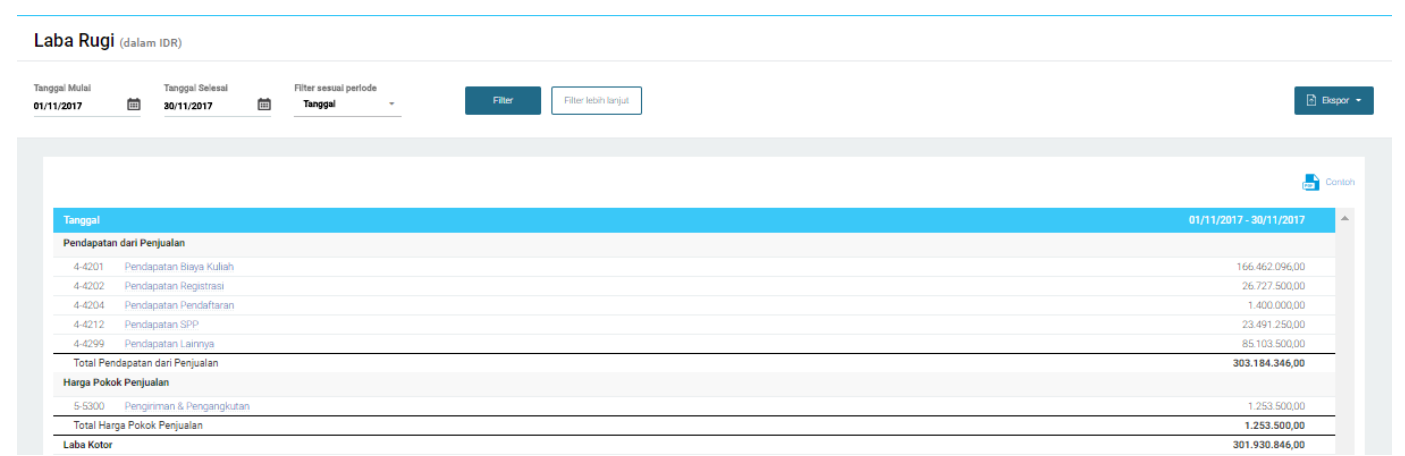

Gambar 11 Tampilan laporan laba rugi dalam program Jurnal

Gambar 11. Tampilan tersebut berasal dari data penjualan yang sudah di masukan ke dalam program, data penjualan yang sudah tercatat tertulis sebagai laporan pendapatan atau laba.

\section{KESIMPULAN}

Dengan adanya implementasi Software Jurnal sebagai Softwafre Akuntansi Online, dapat diambil 3 (tiga) kesimpulan sebagai berikut:

a. Adanya Software Jurnal (Software Akuntansi Online) dinilai dapat mempermudah akuntan dalam menginput data transaksi ke dalam sistem, di mana data transaksi tersebut dapat langsung di import ke dalam sistem sehingga lebih efisien

b. Adanya Software Jurnal (Software Akuntansi Online) dinilai dapat mengurangi banyaknya penggunaan kertas untuk membuat sebuah laporan keuangan apabila terdeteksi kesalahan. Karena akuntan hanya tinggal mengedit data yang salah, maka data tersebut akan dihitung kembali secara otomatis untuk dijadikan sebuah laporan keuangan

c. Pengamanan data yang digunakan dalam Software Jurnal ini sangat baik sehingga kerahasiaan data dapat dipastikan tersimpan dengan baik, tidak perlu lagi khawatir data akan di ambil dan di sabotase oleh orang lain karena hanya pemilik akun yang dapat mengakses data

\section{SARAN}

Berdasarkan penjelasan dari hasil penelitian yang telah di jabarkan sebelumnya oleh penulis, maka dapat disimpulkan dari penjelasan tersebut bahwa terdapat 2 (dua) saran antara lain:

a. Pemanfaatan pada Software Jurnal (Software Akuntansi Online) ini lebih di maksimalkan lagi, karena masih terdapat 14 tab lain yang dapat di telaah serta dilakukan penelitian secara mandiri sebagai optimalisasi penggunaan sistem yang telah mumpuni.

b. Terkait dengan dilakukan nya pengembangan sistem, maka penambahan fitur pasti akan tersedia dalam sistem tersebut sehingga dibutuhkan penelitian lain yang dapat menelaah serta melakukan implementasi yang optimal terhadap perkembangan yang ada termasuk di dalam menu penjualan dalam penelitian ini.

\section{UCAPAN TERIMA KASIH}

Penulis mengucapkan terima kasih kepada pihak yang telah bersedia membantu dalam penelitian ini, terutama kepada Tuhan Yang Maha Esa, karena berkat rahmat dan hidayah-Nya 
penelitian ini dapat berjalan dengan lancar, serta kepada Perguruan Tinggi Raharja yang telah memberi dukungan financial terhadap penelitian ini.

\section{DAFTAR PUSTAKA}

[1] Rahardja, U., Harahap, E. P., \& Pratiwi, S. (2018). Pemanfaatan Mailchimp Sebagai Trend Penyebaran Informasi Pembayaran Bagi Mahasiswa Di Perguruan Tinggi. Technomedia Journal, 2(2), 38-51.

[2] Wardana, W. S., Raharja, U., \& Lutfiani, N. (2018). Penjadwalan Agenda Pelaksanaan Tridharma Perguruan Tinggi Secara Online Menggunakan Google Calendar. Jurnal Teknoinfo, 12(2), 29-34.

[3] Andriani, L., Atmadja, A. T., \& Sinarwati, N. K. (2014). Analisis Penerapan Pencatatan Keuangan Berbasis Sak Etap Pada Usaha Mikro Kecil Menengah (Umkm)(Sebuah Studi Interpretatif Pada Peggy Salon). JIMAT (Jurnal Ilmiah Mahasiswa Akuntansi) Undiksha, 2(1).

[4] Handayani, I., Aini, Q., \& Oktaviani, F. (2016). PENERAPAN SISTEM VALIDASI JURNAL DI PESSTA+ SEBAGAI PENILAIAN ARTIKEL ILMIAH DALAM MENDUKUNG KEGIATAN CIVITAS AKADEMIKA. CSRID (Computer Science Research and Its Development Journal), 8(3), 177-190.

[5] Wibowo, H. A., \& Pujiati, D. (2011). Analisis Rasio Keuangan dalam Memprediksi Perubahan Laba Pada Perusahaan Real Estate dan Property di Bursa Efek Indonesia (BEI) dan Singapura (SGX). The Indonesian Accounting Review, 1(02), 155-178.

[6] Dewi, A. S. M., \& Wirajaya, A. (2013). Pengaruh struktur modal, profitabilitas dan ukuran perusahaan pada nilai perusahaan. E-Jurnal Akuntansi, 358-372.

[7] Komarasari, W. (2017). Pengaruh kapasitas sumber daya manusia, pemanfaatan teknologi informasi dan pengendalian intern akuntansi terhadap keterandalan pelaporan keuangan daerah (Pada SKPD Kabupaten Bantul Bagian Akuntansi dan Keuangan). Prodi Akuntansi UPY.

[8] Septiawan, O., \& Amanah, L. (2018). FAKTOR-FAKTOR YANG MEMPENGARUHI KETERANDALAN PELAPORAN KEUANGAN DAERAH. Jurnal Ilmu dan Riset Akuntansi, 6(11).

[9] Untung, R., Muhamad, Y., \& Eva, R. Optimalisasi Key Performance Indicators (KPI) Melalui Pendekatan Balance Scorecard Upaya Mengimplementasikan Performance Management System (PMS) Pada Perguruan Tinggi. CCIT Journal ISSN, 6(2).

[10] Jurnal, "Menu Home“, https://www.jurnal.id/id diakses tgl 9 Maret 2017

[11] Inanda, S. (2007). Analisis Laporan Keuangan Sebagai Alat Penilaian Kinerja Keuangan Pada PT. Pertamina EP. Area Rantau-Aceh Tamiang. Analisis Laporan Keuangan Sebagai Alat Penilaian Kinerja Keuangan Pada PT. Pertamina EP. Area Rantau-Aceh Tamiang.

[12] WINARNO, J. (2003). PENGEMBANGAN SISTEM INFORMASI PEMBAYARAN PASIEN RAWAT INAP ON-LINE UNTUK PEMANTAUAN PENDAPATAN FUNGSIONAL DI RUMAH SAKIT ORTOPEDI PROF. DR. $R$. SOEHARSO SURAKARTA (Doctoral dissertation, PROGRAM PASCASARJANA UNIVERSITAS DIPONEGORO).

[13] Rahardja, U., Aini, Q., \& Meytasari, R. (2017). Pemanfaatan Fungsi Etalase Artikel Untuk Meningkatkan Traffic Rank Website ZPreneur. Technomedia Journal, 1(2), 75-89.

[14] Kuntoro, P. T., Untung, R., \& Siti, C. (1978). Pengontrolan Mutu Sistem Informasi Dengan Metode Database Self Monitoring. CCIT Journal ISSN, 8282. 
[15] Rahardja, U. (2007). Analisis Kelayakan Investasi Digital Dashboard pada Manajemen Akademik Perguruan Tinggi: Studi Kasus pada Perguruan Tinggi Raharja. Fakultas Ilmu Komputer. Universitas Indonesia, Jakarta.

[16] Rahardja, U., Aini, Q., \& Santoso, N. P. L. (2018). Pengintegrasian YII Framework Berbasis API pada Sistem Penilaian Absensi. SISFOTENIKA, 8(2), 140-152.

[17] Jurnal., "Menu About", https://www.jurnal.id/id/about us diakses tgl 9 Maret 2017.

[18] Rahardja, U., Aini, Q., \& Zuliana, S. R. (2016). METODE LEARNING MANAGEMENT SYSTEM (LMS) IDU UNTUK MENDUKUNG KEGIATAN BELAJAR MENGAJAR MIT PADA PERGURUAN TINGGI RAHARJA. CICES Journal, 2(2), 156-172.

[19] Rahmani, A, 2018, Kenali 7 Ciri-Ciri Ini Sebelum Memilih Software Akuntansi Online, https://www.jurnal.id/id/blog/2018/kenali-7-ciri-ciri-ini-sebelum-memilih-softwareakuntansi-online diakses tgl 23 Mei 2018.

[20] Rahardja, U., Dewi, E.N. and Lutfiani, N., 2017. Peningkatan Rank Webometrics Menggunakan Metode Inbound Dan Outbound Pada Perguruan Tinggi. Sisfotenika, 7(1).

[21] Guritno, S., Rahardja, U., \& Setiatmi, V. (2008). ACCESS RESTRICTION SEBAGAI BENTUK PENGAMANAN DENGAN METODE IP TOKEN. CCIT Journal, 1(3), 197207.

[22] Jurnal, "Seaman apakah data-data saya dengan Jurnal online?", https://www.jurnal.id/id/pricing diakses tgl 9 Maret 2017.

[23] Rahardja, U., Aini, Q., \& Enay, N. (2017). Optimalisasi Dashboard pada Sistem Penilaian Sebagai Media Informasi di Perguruan Tinggi. Sisfotenika, 7(2), 167-176.

[24] Rachmawati, S., \& Nurjanah, N. (2017). IMPLEMENTASI DATA KEUANGAN DENGAN ZAHIR ACCOUNTING PADA PT. ANUGERAH ANALISIS SEMPURNA. JURNAL AKUNTANSI, EKONOMI dan MANAJEMEN BISNIS, 5(2), 267-273.

[25] Maharsi, S. (2004). Pengaruh Perkembangan Teknologi Informasi Terhadap Bidang Akuntansi Manajemen. Jurnal Akuntansi dan keuangan, 2(2), 127-137.

[26] Pertiwi, D. H. (2015). Perancangan Sistem Informasi Aset Tetap Perusahaan Menggunakan Metode Pengembangan Evolusioner. CSRID (Computer Science Research and Its Development Journal), 7(2), 105-112.

[27] Rukmiyati, N. M. S., \& Budiartha, I. K. (2016). Pengaruh Kualitas Sistem Informasi, Kualitas Informasi dan Perceived Usefulness pada Kepuasan Pengguna Akhir Software Akuntansi (Studi Empiris pada Hotel Berbintang di Provinsi Bali). E-Jurnal Ekonomi dan Bisnis Universitas Udayana.

[28] Rudiantoro, R., \& Siregar, S. V. (2012). Kualitas laporan keuangan umkm serta prospek implementasi SAK ETAP. Jurnal Akuntansi dan Keuangan Indonesia, 9(1), 1-21.

[29] Saleh, T., \& Darwanis, U. B. (2012). Pengaruh Kualitas sistem Informasi terhadap kualitas informasi akuntansi dalam upaya meningkatkan kepuasan pengguna software akuntansi pada pemerintah Aceh. Jurnal Akuntansi ISSN, 2302, 0164.

[30] Weharima, A. (2006). Manfaat Akuntansi Pertanggungjawaban Sebagai Alat Bantu Bagi Manajemen Dalam Menunjang Efektivitas Pengendalian Biaya Pemasaran (Studi Kasus pada PT. PLN Unit Bisnis Distribusi Jabar dan Banten) (Doctoral dissertation, Universitas Widyatama). 